\section{Kidney \\ Blood Pressure Research}

\title{
Relaxin-2 Does Not Ameliorate Nephropathy in an Experimental Model of Type-1 Diabetes
}

\author{
Thomas Bernd Dschietziga,b Katharina Krause-Relle ${ }^{\mathrm{c}, \mathrm{d}} \quad$ Maud Hennequin ${ }^{\mathrm{e}}$ \\ Karoline von Websky,d Jan Rahnenführer,d Jana Rupperta Hans Jürgen Gröna \\ Franz Paul Armbruster ${ }^{a}$ Ross A. D. Bathgate ${ }^{f}$ Joerg R. Aschenbach ${ }^{e}$ \\ Wolf-Georg Forssmanng Berthold Hocher ${ }^{c, d}$
}

aImmundiagnostik AG, Bensheim; ${ }^{b}$ Department of Cardiology and Angiology; ${ }^{\mathrm{c} C e n t e r}$ for Cardiovascular Research, Charité Berlin, Campus Mitte; IInstitute for Nutritional Science, University of Potsdam;

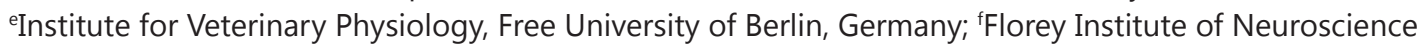
and Mental Health, and Department of Biochemistry and Molecular Biology, University of Melbourne, Melbourne, Australia; 9PHARIS Biotec, Hannover, Germany

\section{Key Words}

Diabetic nephropathy $•$ Diabetic cardiomyopathy $・$ Fibrosis $・$ Inflammation $\bullet$ Relaxin

\begin{abstract}
Background/Aims: In diabetic nephropathy (DN), the current angiotensin-II-blocking pharmacotherapy is frequently failing. For diabetic cardiomyopathy (DC), there is no specific remedy available. Relaxin-2 (RIx) - an anti-fibrotic, anti-inflammatory, and vasoprotecting peptide - is a candidate drug for both. Methods: Low-dose $(32 \mu \mathrm{g} / \mathrm{kg} /$ day) and high-dose $(320 \mu \mathrm{g} / \mathrm{kg} /$ day) Rlx were tested against vehicle $(\mathrm{n}=20$ each) and non-diabetic controls $(\mathrm{n}=$ 14) for 12 weeks in a model of type-1 diabetes induced in endothelial nitric oxide synthase knock-out (eNOS-KO) mice by intraperitoneal injection of streptozotocin. Results: Diabetic animals showed normal plasma creatinine, markedly increased albuminuria and urinary malonyldialdehyde, elevated relative kidney weight, glomerulosclerosis, and increased glomerular size, but no relevant interstitial fibrosis. Neither dose of Rlx affected these changes although the drug was active and targeted plasma levels were achieved. Of note, we found no activation of the renal TGF- $\beta$ pathway in this model. In the hearts of diabetic animals, no fibrotic alterations indicative of DC could be determined which precluded testing of the initial hypothesis. Conclusions: We investigated a model showing early DN without overt tubulointerstitial fibrosis and activation of the TGF- $\beta$-Smad-2/3 pathway. In this model, Rlx proved ineffective; however, the same may not apply to other models and types of diabetes.
\end{abstract}




\section{Kidney Blood Pressure Research}

Dschietzig/Krause-Relle/Hennequin et al.: Relaxin and Diabetic Nephropathy

\section{Introduction}

In spite of the enormously rising prevalence of diabetes mellitus in industrialized countries [1], clinical medicine as well as health economy are equally challenged to manage the different facets of diabetic end-organ damage. Among these deleterious ramifications of diabetes, diabetic nephropathy (DN) plays the major role and represents the leading cause worldwide of end-stage renal disease [2]. Likewise, diabetic cardiomyopathy (DC), defined as diastolic and/or systolic dysfunction in the absence of hypertension and coronary artery disease $[3,4]$, is another serious complication contributing to the overall diabetic risk burden. Prevention and treatment of DN are based on the control of hyperglycemia, the treatment of concomitant classic risk factors, and the therapeutic inhibition of the renin-angiotensinaldosterone system (RAAS) [5, 6]. However, angiotensin-converting enzyme inhibitors or angiotensin receptor blockers are frequently ineffective in preventing DN despite an optimal control of hyperglycemia and risk factors. For DC, no specific pharmacological therapy at all has been identified hitherto. This illustrates the pathophysiological involvement of pathways distinct from RAAS and the urgent need for novel therapeutic approaches.

The insulin-related endogenous peptide hormone relaxin-2 (Rlx) may pose such a novel candidate drug. Signaling via its cognate G protein-coupled receptor, RXFP1 $[7,8]$, and the glucocorticoid receptor [9] Rlx has been demonstrated to exert the following effects that may address major hallmarks of DN and DC: Above all, Rlx is one of the most powerful anti-fibrotic agents in many different models of heart, lung, kidney, and liver fibrosis [1015]. It has recently been shown to be superior to enalapril in experimental cardiac fibrosis [16]. Rlx is a renal vasodilator stimulating the NO-cGMP axis $[17,18]$. It protects against endothelial dysfunction [19] and early vascular inflammation [20], and counter-acts the vasoconstrictory as well as pro-inflammatory actions of endothelin-1 [21]. Moreover, Rlx inhibits several markers of oxidative stress in different animal models [14, 19, 22]. However, in the type- 1 diabetic mRen- 2 rat, Rlx affected end-organ damage differentially: DC was markedly improved as reflected by less interstitial myocardial fibrosis and better diastolic function [23]. In contrast, DN as assessed by urinary albumin loss, interstitial collagen, and glomerulosclerosis was not modified at all [24]. In this work, we sought to investigate whether this striking dissociation represents a species-related phenomenon. Accordingly, we investigated the effects of two different doses of Rlx in an established mouse model of type-1 diabetes which closely mimics the pathophysiology of human DN [25-27] and DC [28].

\section{Materials and Methods}

\section{Study design}

This study was carried out in strict accordance with the recommendations in the "Guide for the Care and Use of Laboratory Animals of the National Institutes of Health". The protocol was approved by the local animal welfare committee of the German State of Berlin (project no. G0209/10). All surgical procedures were performed under inhalation anesthesia with isoflurane, and all efforts were made to minimize suffering.

Eight-week old male eNOS (NOS3) knock out C57BL/6J mice (C57BL/6J-Nos3tm1Unc; n= 74) were obtained from The Jackson Laboratory (Bar Harbor, ME, USA). The eNOS \% genotype is known to greatly aggravate albuminuria in diabetic models $[26,27,29,30]$; and it was the main focus of our study to evaluate the effect of Rlx on this important clinical end-point of DN. The gain of albuminuria is particularly high in eNOS-KO animals treated with the high-dose STZ protocol [25], which for us outweighed the greater propensity for non-specific cytotoxic effects related to the high-dose regimen. At last, eNOS-KO on a BLKS background are more susceptible to DN than B6 animals $[25,30]$, but here our choice was merely guided by the issue of commercial availability at study beginning.

In accordance with local institutional guidelines for the care and use of laboratory animals, mice were housed under standardized conditions (12 h light/dark cycle, temperature of $23{ }^{\circ} \mathrm{C}$, humidity of 50-60\%) and kept in solitary cages with commercial standard diet (Ssniff Spezialdiäten GmbH, Soest, Germany) 


\section{Kidney \\ Blood Pressure Research}

Kidney Blood Press Res 2015;40:77-88

\begin{tabular}{l|l}
\hline DOI: $10.1159 / 000368484$ & C) 2015 S. Karger AG, Basel \\
Publisned ontIne: IVIarch 05, 2015 & www.karger.com/kbr
\end{tabular}

Dschietzig/Krause-Relle/Hennequin et al.: Relaxin and Diabetic Nephropathy

and water ad libitum. Before induction of diabetes by streptozotocin (STZ), baseline blood pressure was measured using the non-invasive tail-cuff method and metabolic cages were performed. Then mice intraperitoneally received STZ (100 mg/kg body weight) on 2 consecutive days. Four weeks after STZ treatment, hyperglycemia $>250 \mathrm{mg} / \mathrm{dl}$ was confirmed. The diabetic mice were then randomly divided into the following groups ( $\mathrm{n}=20$ each): vehicle, low-dose Rlx $(32 \mu \mathrm{g} / \mathrm{kg} / \mathrm{d})$, and high-dose Rlx ( $320 \mu \mathrm{g} / \mathrm{kg} / \mathrm{d})$. Another 14 mice served as non-diabetic controls and received vehicle after they had been administered citrate buffer instead of STZ in equal volume. The high dose Rlx was chosen based on previous reports in mice and rats [31,32] (see also Discussion). The lower dose was based on the mere rationale that many long-term effects of peptides can also be observed at sub-maximum levels.

Treatment was conducted for 12 weeks which necessitated the implantation of Alzet-2006 osmotic mini-pumps (Charles River) at beginning and at week 6 of Rlx/vehicle administration. The pump reservoirs $(250 \mu \mathrm{l})$ were loaded with vehicle alone, $0.105 \mathrm{mg}$, and $1.05 \mathrm{mg}$ Rlx for the control, low-dose, and highdose groups, respectively. At treatment weeks 5 and 10, baseline measurement of blood pressure and metabolic cages were performed; blood glucose levels were determined immediately before the different Alzet implantations. Final procedures in treatment week 12 (i. e., week 16 after STZ) included collection of urine and blood samples as well as animal sacrifice including determination of organ wet weights and harvest for histology.

\section{Histology}

Renal and myocardial morphology (interstitial fibrosis, perivascular fibrosis, glomerulosclerosis, myocyte diameter, and media-lumen ratio of blood vessels) was measured as described previously [33]. In brief, glomerular matrix expansion was evaluated on periodic acid-Schiff (PAS)-stained slides by rating the percentage of the PAS-positive areas within the glomerulus using a subjective, semi-quantitative score system (grade I-IV) by two investigators who were blinded to the study groups of the animals. The severity of interstitial fibrosis was evaluated after Sirius Red-staining using computer-aided devices. Thirty microscopic pictures per kidney/heart section were transferred to a PowerMAC via Hitachi CCD camera. After manually setting a threshold using a randomly chosen subset of the pictures, we measured the relationship of Sirius Red-stained area (connective tissue) to total area of the picture using ImageJ, an image-processing software (shareware from the National Institutes of Health). Accordingly, microscopic pictures of kidney/heart sections after Elastica-van Gieson staining that showed arterial blood vessels were generated. We measured the area contents of the media and the lumen of intra-renal arteries using Imagej; thereafter, media/lumen ratio was calculated to serve as marker for arterial wall thickening. Likewise, we determined myocyte diameters in myocardium.

\section{Western Blotting}

Proteins of murine kidney were extracted as previously described [34], additionally supplemented with inhibitor of phosphatases (PhosStop, Roche diagnostics, Indianapolis, IN). Proteins were electrophoretically separated and transferred to a nitrocellulose membrane using semi-dry equipment. The membranes were blocked and incubated with primary antibodies against TGF- $\beta$ (sc-146, Santa Cruz Biotechnology, Santa Cruz, CA) or phosphorylated Smad 2/3 (sc-11769-R, Santa Cruz). Immunostaining with antibodies against total Smad 2/3 (sc-6202, Santa Cruz) or actin (A5060, Sigma-Aldrich) was used as internal control. Then membranes were incubated with host-specific HRP-coupled secondary antibodies (sc-2054 or sc-2056, Santa Cruz). Immunoreactive bands were visualized with chemoluminescence detection as described before [35] and exposure to an autoradiography film (Amersham Hyperfilm ECL (GE healthcare, Chalfont St. Giles, UK)). Photos were scanned and the protein bands were quantified using AlphaEaseFC software (Alpha Innotech, San Leandro, CA).

\section{Biochemical parameters}

Urinary albumin was measured using an enzyme-linked immuno-sorbent assay (ELISA) according to the manufacturer's instructions (Immundiagnostik, Bensheim, Germany). Urinary and plasma creatinine were measured spectrophotometrically based on the Jaffé reaction of creatinine with alkaline picrate (Limbach Laboratory, Heidelberg, Germany). Urinary malonyldialdehyde (MDA) was determined by HPLC (Immundiagnostik AG). 


\section{Kidney \\ Blood Pressure Research}

Dschietzig/Krause-Relle/Hennequin et al.: Relaxin and Diabetic Nephropathy

Synthetic Rlx: biological effects and plasma levels

Synthetic human relaxin-2 was synthesized by PHARIS Biotec (Hannover, Germany). Its biological effects were verified as follows:

Ligand binding assay. We performed competition binding experiments utilizing HEK-293T cells stably transfected with RXFP1 and europium-labeled human relaxin-2 according to Shabanpoor et al. [36]. Briefly, cells were plated out in 96-well Isoplates with white walls and clear bottoms precoated with polyL-lysine. Competition binding experiments were carried out using europium-labeled Rlx in the presence of increasing concentrations of synthetic Rlx or of the reference substance, recombinant human relaxin-2 (Corthera, San Carlos, USA). Non-specific binding was determined with an excess (500 nM) of unlabeled Rlx. Each concentration point was performed in triplicate and peptides were tested in at least three independent assays to confirm activity. Curves were fitted using a one site-binding model in GraphPad Prism 4.0 (GraphPad Software, San Diego, CA, USA). The inhibition constants $\left(\mathrm{K}_{\mathrm{i}}\right)$ as a measure of peptide activity were determined from the $\mathrm{IC}_{50}$ values using the Cheng-Prusoff equation, with $\mathrm{pKi}$ being the negative decadic logarithm of the inhibition constant $\mathrm{K}_{\mathrm{i}}$.

Functional cAMP assay: cAMP reporter gene assays were carried out as described by Yan et al. [37]. Briefly, HEK-293T cells stably expressing RXFP1 and a pCRE- $\beta$-galactosidase reporter plasmid were utilized to determine the ability of synthetic Rlx to activate RXFP1-related signaling. Stimulation of RXFP1 results in the activation of adenylate cyclase and consequently in an increase in cAMP and subsequent activation of the pCRE reporter. Cells were incubated for 6 hours with increasing concentrations of synthetic Rlx or of the reference substance, recombinant human relaxin-2 (Corthera, San Carlos, USA). Each concentration point was performed in triplicate and peptides were tested in at least three independent experiments. Data were analyzed with GraphPad Prism 4.0 (GraphPad Software, San Diego, CA, USA), and a nonlinear regression sigmoidal dose-response (variable slope) model was used to plot curves and calculate $\mathrm{pEC}_{50}$ values, with $\mathrm{pEC}_{50}$ being the negative decadic logarithm of the half-maximum concentration.

Upon sacrifice of the animals, blood was collected for the determination of therapeutic Rlx levels by a commercially available ELISA for human Rlx (Immundiagnostik, Bensheim, Germany). Plasma was diluted 1:44 in assay buffer, and the ELISA was used according to the manufacturer's instructions.

\section{Statistical analyses}

All values are given as means \pm standard error of the mean (SEM). Statistical analyses were performed with SPSS 18.0 for Windows (SPSS Inc., Chicago, IL, USA). For comparisons between the four groups of interest, the Kruskal-Wallis ANOVA on ranks was used. If global significance was indicated pair-wise comparisons were made with the Mann-Whitney U test and Bonferroni-Holm adjustment of P. For comparisons within groups over time, the Friedman ANOVA on ranks was used followed by Wilcoxon tests with P adjustment as described above. Differences were considered significant if $\mathrm{P}<0.05$ and highly significant if $\mathrm{P}<0.01$.

\section{Results}

\section{Mortality and blood pressure}

In the non-diabetic control group, mortality was $7 \%$ (1 animal of 14). Mortality in the 3 diabetes groups was clearly higher, i. e., $40 \%$ in the vehicle group ( 8 of 20), $55 \%$ in the lowdose Rlx group (11 of 20), and $50 \%$ in the high-dose Rlx group (10 of 20). The prematurely deceased animals were not analysed.

At weeks 5 and 10, systolic blood pressure was decreased in all diabetic animals as compared to non-diabetic controls, with no further effect of Rlx thereon (data not shown).

\section{Blood glucose and body weight baseline vs final}

As summarized in Table 1, diabetic animals did not gain weight significantly and showed severely elevated glucose levels at final examination. These characteristics were not affected by Rlx at either dose. 


\section{Kidney \\ Blood Pressure Research}

Table 1. Body weight and blood glucose (data are mean \pm SEM). ${ }^{*}, \mathrm{P}<0.05$ vs baseline; ${ }^{* *}, \mathrm{P}<0.01$ vs baseline. \#\#, $\mathrm{P}<0.01$ vs non-diabetic controls

\begin{tabular}{|c|c|c|c|c|}
\hline & $\begin{array}{l}\text { Non-diabetic } \\
\text { controls }\end{array}$ & $\begin{array}{c}\text { Diabetes, } \\
\text { vehicle }\end{array}$ & $\begin{array}{l}\text { Diabetes, low- } \\
\text { dose Rlx }\end{array}$ & $\begin{array}{l}\text { Diabetes, high- } \\
\text { dose Rlx }\end{array}$ \\
\hline $\mathrm{n}$ & 13 & 12 & 9 & 10 \\
\hline Body weight, baseline (g) & $19.9 \pm 0.8$ & $21.0 \pm 1.0$ & $20.5 \pm 1.1$ & $20.8 \pm 0.8$ \\
\hline Body weight, final (g) & $31.0 \pm 0.8^{* *}$ & $22.5 \pm 1.4 \# \#$ & $21.8 \pm 1.3 \# \#$ & $23.6 \pm 1.8 \# \#$ \\
\hline Blood glucose, baseline (mg/dl) & $133 \pm 8$ & $158 \pm 10$ & $150 \pm 20$ & $170 \pm 16$ \\
\hline Blood glucose, final (mg/dl) & $145 \pm 18$ & $523 \pm 50 * * \# \#$ & $601 \pm 48^{* * \# \#}$ & $611 \pm 72^{* * \# \#}$ \\
\hline
\end{tabular}

Fig. 1. (A) Albuminuria at baseline and at final examination. Data are given as mean \pm SEM. * $\mathrm{P}<0.05$ vs baseline; **, $\mathrm{P}<0.01$ vs baseline; \#\#, $\mathrm{P}<0.01$ vs non-diabetic control. (B) Urinary levels of malonyldialdehyde (MDA) (in $\mu \mathrm{mol} / \mathrm{l}$ ) normalized to urinary creatinine levels (in $\mathrm{mmol} / \mathrm{l}$ ). Data are given as mean \pm SEM. ${ }^{* *}, \mathrm{P}<0.01$ vs baseline; \#\#, $\mathrm{P}<0.01$ vs non-diabetic control.

\section{Kidney function and urine analysis}

Plasma creatinine levels in non-diabetic controls were $43 \pm 5.2$ and $59 \pm 5.2 \mu \mathrm{mol} / \mathrm{l}$ at baseline and final examination, respectively. In the different diabetic groups, these levels showed a trend towards lower values which did not reach significance (data not shown).

In diabetic controls, albuminuria increased markedly over 16 weeks as compared with non-diabetic controls, and neither dose of Rlx changed these values (Fig. 1A). Regarding diabetes-related oxidative stress, we detected a massive increase in creatinine-normalized urinary MDA levels in the diabetic controls which was not attenuated by the different Rlx regimes (Fig. 1B).

Organ weight and histology (Table 2)

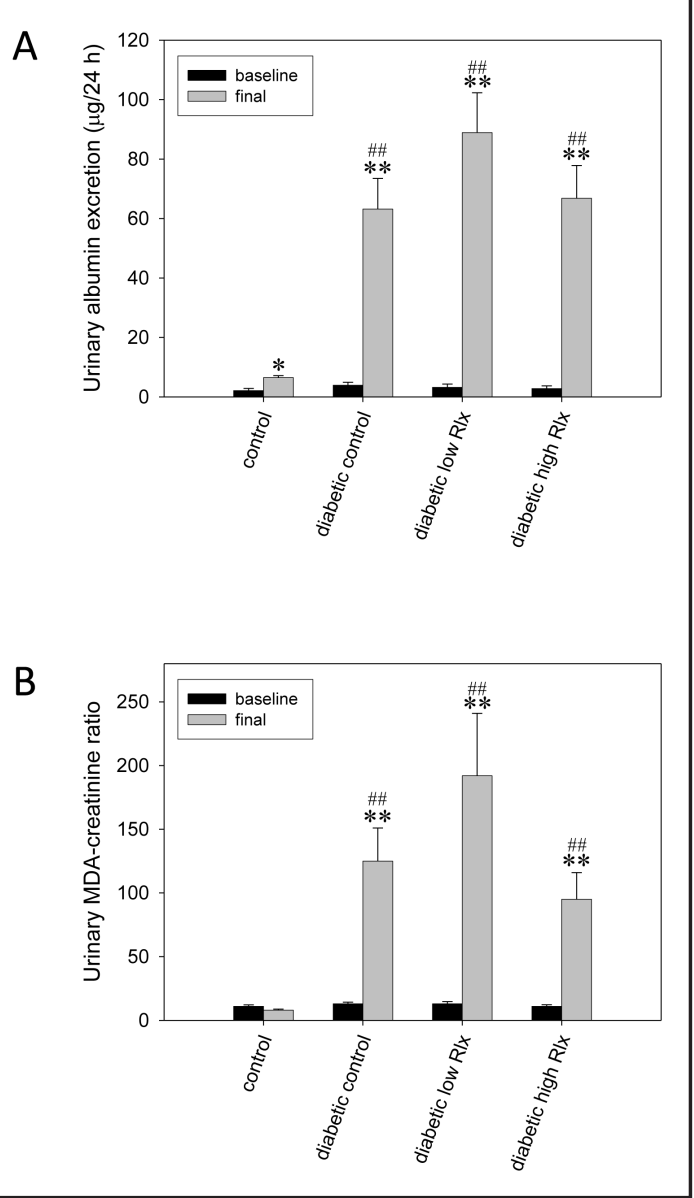

The STZ-induced diabetes elevated the relative weights of the kidneys and liver, but did not change relative heart weight. Rlx treatment had no effect on kidney and liver weight.

With regard to kidney histology, the diabetes-induced increases in glomerulosclerosis score (Fig. 2) and glomerular size were mitigated by neither dose of Rlx. Perivascular and interstitial fibrosis as well as media-to-lumen ratio of intra-renal arteries were not altered in diabetic as compared to non-diabetic animals.

Myocardial perivascular and interstitial fibrosis was not changed during the course of disease in this model. However, myocyte diameters in all diabetic groups decreased significantly in comparison with non-diabetic controls, with neither dose of Rlx showing an effect hereon.

\section{TGF- $\beta$ involvement}

In spite of the non-effectiveness of Rlx to ameliorate renal functional (albuminuria and MDA) and the related histological alterations (glomerulosclerosis and related inflammation) 


\section{Kidney Blood Pressure Research}

Table 2. Organ weights (normalized to body weight [BW]) and histological parameters (data are mean \pm SEM). \#, $\mathrm{P}<0.05$ vs non-diabetic controls; \#\#, $\mathrm{P}<0.01$ vs non-diabetic controls

\begin{tabular}{|c|c|c|c|c|}
\hline & $\begin{array}{l}\text { Non-diabetic } \\
\text { controls }\end{array}$ & $\begin{array}{l}\text { Diabetes, } \\
\text { vehicle }\end{array}$ & $\begin{array}{l}\text { Diabetes, low- } \\
\text { dose Rlx }\end{array}$ & $\begin{array}{l}\text { Diabetes, high- } \\
\text { dose Rlx }\end{array}$ \\
\hline $\mathrm{n}$ & 13 & 12 & 9 & 10 \\
\hline \multicolumn{5}{|l|}{ Organ weights } \\
\hline Kidney weight (mg/g BW) & $9.7 \pm 0.2$ & $16.2 \pm 0.8 \# \#$ & $16.9 \pm 0.3 \# \#$ & $16.5 \pm 0.7 \# \#$ \\
\hline Heart weight (mg/g BW) & $4.2 \pm 0.08$ & $4.4 \pm 0.1$ & $4.1 \pm 0.05$ & $4.1 \pm 0.1$ \\
\hline Liver weight (mg/g BW) & $46.5 \pm 0.9$ & $65.1 \pm 1.2 \# \#$ & $66.2 \pm 2.0 \# \#$ & $70.5 \pm 1.3 \# \#$ \\
\hline \multicolumn{5}{|l|}{ Kidney histology } \\
\hline Glomerulosclerosis score & $2.61 \pm 0.12$ & $3.20 \pm 0.11 \#$ & $3.21 \pm 0.14 \#$ & $3.06 \pm 0.14 \#$ \\
\hline Glomerular size (Pixel) & $3.83 \pm 0.14$ & $4.68 \pm 0.14 \# \#$ & $5.04 \pm 0.26 \# \#$ & $4.67 \pm 0.18 \# \#$ \\
\hline Perivascular fibrosis score & $1.45 \pm 0.06$ & $1.24 \pm 0.03$ & $1.68 \pm 0.11$ & $1.30 \pm 0.04$ \\
\hline Interstitial fibrosis (\%) & $23.6 \pm 1.9$ & $26.5 \pm 2.3$ & $21.5 \pm 1.9$ & $27.5 \pm 1.6$ \\
\hline Media-to-lumen ratio & $2.04 \pm 0.17$ & $2.01 \pm 0.21$ & $1.86 \pm 0.23$ & $1.89 \pm 0.14$ \\
\hline \multicolumn{5}{|l|}{ Myocardial histology } \\
\hline Perivascular fibrosis score & $1.45 \pm 0.07$ & $1.65 \pm 0.09$ & $1.49 \pm 0.06$ & $1.51 \pm 0.07$ \\
\hline Interstitial fibrosis (\%) & $15.3 \pm 2.4$ & $10.2 \pm 1.1$ & $8.7 \pm 1.4$ & $15.2 \pm 3.2$ \\
\hline Myocyte diameter (x $10^{5}$ pixel) & $2.17 \pm 0.04$ & $1.87 \pm 0.02 \# \#$ & $1.85 \pm 0.07 \# \#$ & $1.88 \pm 0.13 \# \#$ \\
\hline
\end{tabular}

Fig. 2. Representative examples of histopathological findings. (A) Non-diabetic control. (B) Diabetic control. (C) Diabetic low-dose Rlx. (D) Diabetic high-dose Rlx. Black asterisk indicates accumulation of PAS-positive glomerular matrix proteins, gray arrow indicates hypercellular mesangial enlargement, black arrow shows adhesion with outer membrane of Bowman capsula, and black triangle points
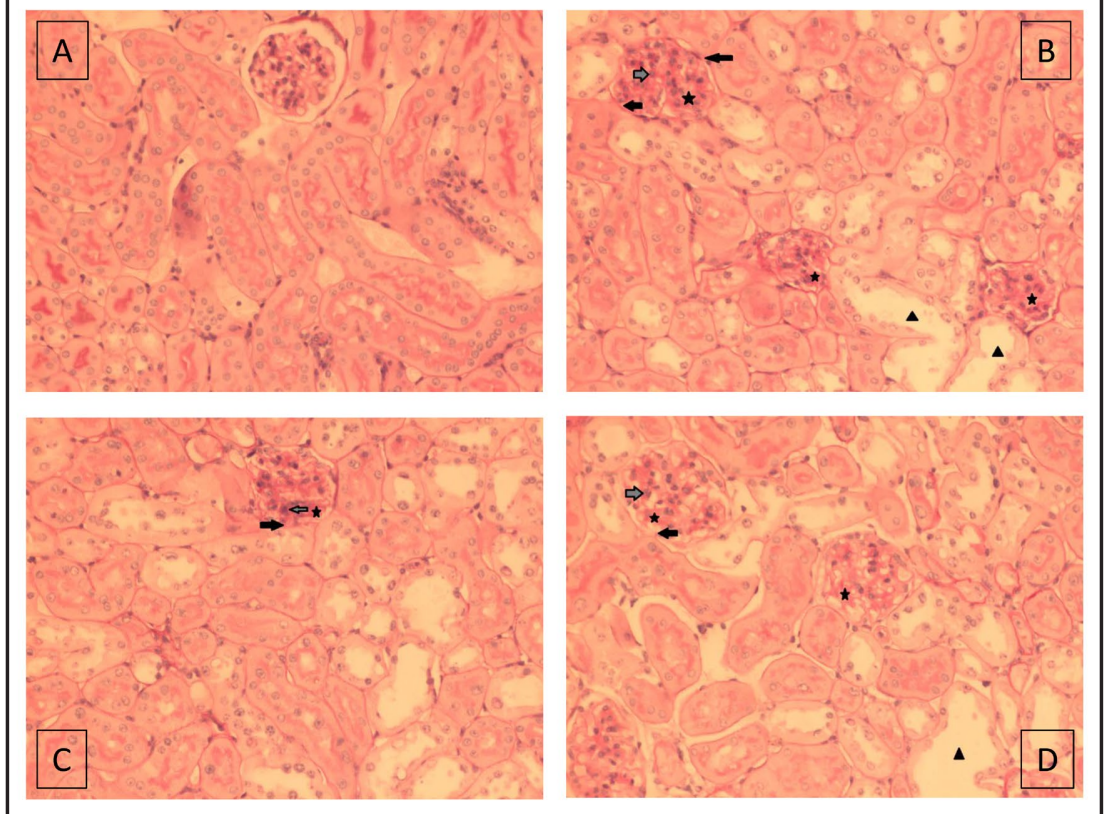
to tubular atrophy.

we sought to determine whether the key target of Rlx's anti-fibrotic action, TGF- $\beta$, contributed to the observed pathology in our model. Fig. 3 shows that renal TGF levels were slightly, but significantly down-regulated in diabetic controls as compared with non-diabetic animals. Similarly, the phosphorylation of the TGF-dependent transcription factors Smad-2 and -3 showed a downward trend in the diabetic groups which reached significance after high-dose Rlx treatment.

\section{Assessment of Rlx activity}

Competition binding experiments utilizing HEK-293T cells yielded a $\mathrm{pK}_{\mathrm{i}}$ of $9.3 \pm$ 0.15 and $9.0 \pm 0.05$ for synthetic Rlx and recombinant Rlx, respectively (data not shown). cAMP reporter gene assays showed a $\mathrm{pEC}_{50}$ of $10.4 \pm 0.05$ for synthetic and $10.2 \pm 0.04$ for recombinant Rlx (not shown). The final therapeutic plasma levels of Rlx were $1.27 \pm 0.24$ and $6.43 \pm 1.0 \mathrm{ng} / \mathrm{ml}$ in the low-dose and high-dose groups, respectively. 


\section{Kidney \\ Blood Pressure Research}

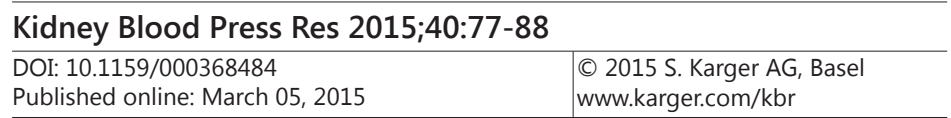

Dschietzig/Krause-Relle/Hennequin et al.: Relaxin and Diabetic Nephropathy

\section{Discussion}

This work aimed at investigating the effect of two different doses of continuously infused sc. Rlx on the development and progression of DN and DC. Our hypothesis of Rlx being a candidate remedy for this diabetesinduced organ damage was based on a large body of experimental evidence indicating remarkably potent anti-fibrotic, reno-protective and reno-vasodilating, endotheliumprotecting, anti-inflammatory, as well as endothelin-1-suppressing effects of the peptide [10-21].

The main findings are as follows: 1) In a mouse model of type-1 diabetes characterized by early and moderate DN (glomerulosclerosis and albuminuria) and high overall mortality, neither a low nor a high dose of Rlx administered for 12 weeks resulted in changes of the course of disease. 2) The fact that TGF- $\beta$, the major target of Rlx's action against fibrotic damage, was obviously not involved in the pathology of our model may lend an explanation to the ineffectiveness of the peptide. 3 ) In our model, myocardial fibrosis, a hallmark of DC, was not induced so that the above-mentioned working hypothesis for DC could not be tested within the design of this study.

The eNOS-knockout/STZ model used here was introduced by Nakagawa et al. [27] and its principal features were confirmed by Kanetsuna et al. shortly thereafter [26]. The observed high mortality in our study corresponds well with that reported in Nakagawa's work in which it was $\sim 50 \%$ at week 20 [27]. Accordingly, this model is characterized by an inherent survival bias. In line with the early reports on this model $[26,27]$, we observed an early and moderate type of DN with plasma creatinine still in the normal range and increased relative kidney weight. The prevailing histological findings were glomerulosclerosis as well as glomerular enlargement (Table 2). The pathology did not involve interstitial fibrosis or wall thickening of intra-renal arteries. However, the massive increase in urinary MDA (Fig. 1B) reflected the diabetes-related inflammatory rise of oxidative stress. As already mentioned in the Study Design section, the lower susceptibility of C57BL/6J as compared to BLKS mice regarding DN may have contributed to the mildness of histological findings $[25,30]$. In retrospect, feeding a high-fat diet might have aggravated our model which was reported particularly for eNOS-KO mice [38].

At first sight, the ineffectiveness of Rlx to ameliorate DN in this study may appear contradictory to the many positive experimental studies mentioned above. In more detail, Rlx was effective as anti-fibrotic agent in rodent models of renal papillary necrosis [39], glomerulonephritis [40], sub-total nephrectomy [41], spontaneous hypertension [12], and 


\section{Kidney Blood Pressure Research}

unilateral ureteric obstruction [11]. At closer look, however, those were models of severe interstitial fibrosis with concomitant glomerular sclerosis, and TGF- $\beta$ was the major inducer of pathology. In our type- 1 diabetic model, TGF- $\beta$ was obviously not activated, nor was its key down-stream transcription factor, phosphor-Smad-2/3 (Fig. 3). This may explain the missing efficacy of Rlx on this disease phenotype since the interference with TGF- $\beta$ signaling poses the established pathway of Rlx's renal anti-fibrosis [42, 43]. Keeping this in mind, our results do corroborate the study conducted by Wong et al. in mRen2/STZ rats [24] in which Rlx similarly failed to affect a type-1 diabetes-related renal pathology with prevailing glomerulosclerosis and albuminuria, little if any interstitial fibrosis, and preserved glomerular filtration rate.

Notwithstanding these considerations, the question arises as to why TGF- $\beta$ was not upregulated in this model as well as in the mRen 2 rat. First, overt TGF activation promoting tubulo-interstitial fibrosis - that can be detected in a whole-kidney Western blot - was usually found very late in comparable mice models of DN: A modest up-regulation of interstitial collagen III was reported at week 20 after STZ earliest [26, 29, 44]. We had to stop our study prematurely because of the high mortality and sacrifice our animals at week 16 after STZ according to German animal welfare regulations. Thus, it might well have been too early to detect and treat this later stage of DN which presumably involves TGF. On the other hand, TGF- $\beta$ is also a pivotal mediator of the early occurring diabetic glomerulosclerosis since it is usually up-regulated early in mesangial cells and podocytes [45]. It was not evaluated in the studies that established the eNOS-KO/STZ model $[26,27,29]$ whether glomerular TGF was activated, but if we assume so, why then could Rlx have been ineffective? Besides the absence of overt TGF- $\beta$ activation in their rat model, Wong and coworkers [24] also reported on the lack of RXFP1 protein expression in mesangial cells. As these cells are the main players in early glomerulosclerosis [45] this would lend another explanation for the ineffectiveness of Rlx. The ultimate question, however, if there is RXFP1 protein expression in mouse mesangial cells cannot be answered conclusively at present: It is much more difficult to isolate primary mouse glomerular cells and, more importantly, there is no reliable antibody against mouse RXFP1 to date that could be used for immunohistochemistry. Accordingly, we are not aware of any findings elucidating this issue. Instead of being activated, TGF- $\beta$ was even slightly, but significantly down-regulated in the diabetic control group. This can be a chance finding in a small group. On the other hand, our type-1 diabetic model is associated with severe illness and cachexia (cp. bodyweight in Table 1), and this may have impacted on the activation of latent TGF- $\beta$. We hypothesize as follows: Plasmin and thrombospondin are the main TGF activators [46]. The activation of plasmin, in turn, is decreased in cachexia states owing to the up-regulation of plasminogen activator inhibitor [47]. Thrombospondin is mainly synthesized in adipose tissue [48] which is progressively lost in cachexia although, admittedly, there is also thrombospondin expression in the kidneys [29].

In many models of renal pathology, oxidative stress and TGF- $\beta$ activation are intricately linked and act synergistically [49]. In our model, oxidative stress, as measured by urinary MDA, and TGF regulation were dissociated. It is, however, well conceivable that increased oxidative stress acted independently here, e. g., by inactivating neuronal NOS-derived NO which plays an established role in this particular model [26]. Alternatively, oxidative stress is known to activate the JNK pathway, a major player in renal disease, via thioredoxin oxidation $[50,51]$. With regard to the eNOS-knockout model chosen, we would like to emphasize that first, the NO-generating renal effect of Rlx is mediated via neuronal NOS [43], and second, that a pathological decline of eNOS function is also a fundamental contributor to human DN $[52,53]$. In other words, our model does not a priori preclude or limit the efficacy of the candidate drug.

Biological inactivity can be largely excluded as a potential cause for the inefficacy of Rlx in our model. First, the $\mathrm{pK}_{\mathrm{i}}$ and $\mathrm{pEC}_{50}$ values obtained with our synthetic and with recombinant Rlx in HEK-293T cells were identical and correspond well with data reported in the literature [54-59]. Second, we determined final plasma values within the targeted 


\section{Kidney \\ Blood Pressure Research}

range. For comparison, Samuel et al. [32] reported plasma levels between $20-40 \mathrm{ng} / \mathrm{ml}$ in mice at day 14 using a moderately higher dose of Rlx, 500 instead of $320 \mu \mathrm{g} / \mathrm{kg} / \mathrm{d}$. The levels reported by Samuel and the level in the high-dose group measured here, $\sim 6 \mathrm{ng} / \mathrm{ml}$, are around the circulating level at maximum renal vasodilator response, $\sim 11 \mathrm{ng} / \mathrm{ml}$, as determined by Danielson and coworkers in conscious rats [31].

One may wonder why the Rlx-induced small, but significant inhibition of Smad activation was not followed by a therapeutic benefit. We strongly believe that this is attributable to the fact that this signaling path was not up-regulated at all in the diabetic controls, which is in striking contrast to all cases in which Rlx was beneficial by mitigating an increased Smad phosphorylation [43].

We were not able to verify our hypothesis regarding DC in our model because no myocardial fibrosis developed. The decrease in myocyte diameter was certainly related to the cachexia of the diabetic animals. Admittedly, the absence of fibrosis cannot exclude DC which is characterized by generalized systolic and diastolic dysfunction as well as metabolic disturbances in the STZ model [28]. However, more detailed investigations including echocardiography and/or cardiac catheterization were not planned for this study owing to logistical considerations and animal welfare regulations. In the type-1 diabetic mRen2/ STZ rat model, Samuel et al. reported beneficial effects of Rlx on myocardial fibrosis and the related diastolic dysfunction [23]. As discussed above, Rlx was not beneficial regarding the renal pathology of the very same model [24]. These facts may indicate 1) model-related differences in the development of DC (eNOS-KO/STZ mouse vs mRen2/STZ rat) and 2) organ-related differences (kidney vs heart) regarding the Rlx-susceptibility of the pathways involved.

\section{Conclusion}

We investigated a model showing early DN without overt tubulo-interstitial fibrosis and activation of the TGF- $\beta$-Smad- $2 / 3$ pathway. In such a model, therapeutic doses of Rlx proved ineffective on readouts of disease severity. However, the same may not apply to other models and types of diabetes. Instead, Rlx should be tested in type- 2 diabetes and the related endorgan damage.

\section{Disclosure Statement}

PHARIS Biotec (W. G. F.) manufactures and distributes shRlx-2 for laboratory use.

\section{Abbreviations}

DN, diabetic nephropathy; DC, diabetic cardiomyopathy; RAAS, renin-angiotensinaldosterone system; Rlx, human relaxin-2; STZ, streptozotocin; MDA, malonyldialdehyde; PAS, periodic acid-Schiff; ELISA, enzyme-linked immuno-sorbent assay.

\section{Acknowledgements}

This work was supported by a grant from the German Ministry for Education and Research (AiF KF2181502FR9) given to TBD and WGF. 


\section{Kidney \\ Blood Pressure Research}

\begin{tabular}{l|l}
\hline Kidney Blood Press Res 2015;40:77-88 \\
\hline DOI: 10.1159/000368484 & $\begin{array}{l}\text { C } 2015 \text { S. Karger AG, Basel } \\
\text { www.karger.com/kbr }\end{array}$ \\
\hline Publisned onIne: IVarch 05, 2015 &
\end{tabular}

Dschietzig/Krause-Relle/Hennequin et al.: Relaxin and Diabetic Nephropathy

\section{References}

1 Gray SP, Cooper ME: Diabetic nephropathy in 2010: Alleviating the burden of diabetic nephropathy. Nat Rev Nephrol 2011;7:71-73.

2 van DS, Beulens JW, van der Schouw YT, Grobbee DE, Neal B: The global burden of diabetes and its complications: an emerging pandemic. Eur J Cardiovasc Prev Rehabil 2010;17:S3-S8.

3 Hayat SA, Patel B, Khattar RS, Malik RA: Diabetic cardiomyopathy: mechanisms, diagnosis and treatment. Clin Sci (Lond) 2004;107:539-557.

4 Rubler S, Dlugash J, Yuceoglu YZ, Kumral T, Branwood AW, Grishman A: New type of cardiomyopathy associated with diabetic glomerulosclerosis. Am J Cardiol 1972;30:595-602.

5 Mann JF, Schmieder RE, McQueen M, Dyal L, Schumacher H, Pogue J, Wang X, Maggioni A, Budaj A, Chaithiraphan S, Dickstein K, Keltai M, Metsarinne K, Oto A, Parkhomenko A, Piegas LS, Svendsen TL, Teo KK, Yusuf S: Renal outcomes with telmisartan, ramipril, or both, in people at high vascular risk (the ONTARGET study): a multicentre, randomised, double-blind, controlled trial. Lancet 2008;372:547-553.

6 Yusuf S, Teo KK, Pogue J, Dyal L, Copland I, Schumacher H, Dagenais G, Sleight P, Anderson C: Telmisartan, ramipril, or both in patients at high risk for vascular events. N Engl J Med 2008;358:1547-1559.

7 Bathgate RA, Halls ML, van der Westhuizen ET, Callander GE, Kocan M, Summers RJ: Relaxin family peptides and their receptors. Physiol Rev 2013;93:405-480.

8 Hsu SY, Nakabayashi K, Nishi S, Kumagai J, Kudo M, Sherwood OD, Hsueh AJ: Activation of orphan receptors by the hormone relaxin. Science 2002;295:671-674.

-9 Dschietzig T, Bartsch C, Stangl V, Baumann G, Stangl K: Identification of the pregnancy hormone relaxin as glucocorticoid receptor agonist. FASEB J 2004;18:1536-1538.

10 Bennett RG, Kharbanda KK, Tuma DJ: Inhibition of markers of hepatic stellate cell activation by the hormone relaxin. Biochem Pharmacol 2003;66:867-874.

11 Hewitson TD, Ho WY, Samuel CS: Antifibrotic properties of relaxin: in vivo mechanism of action in experimental renal tubulointerstitial fibrosis. Endocrinology 2010;151:4938-4948.

12 Lekgabe ED, Kiriazis H, Zhao C, Xu Q, Moore XL, Su Y, Bathgate RA, Du XJ, Samuel CS: Relaxin reverses cardiac and renal fibrosis in spontaneously hypertensive rats. Hypertension 2005;46:412-418.

$>13$ Samuel CS, Unemori EN, Mookerjee I, Bathgate RA, Layfield SL, Mak J, Tregear GW, Du XJ: Relaxin modulates cardiac fibroblast proliferation, differentiation, and collagen production and reverses cardiac fibrosis in vivo. Endocrinology 2004;145:4125-4133.

14 Sasser JM, Molnar M, Baylis C: Relaxin ameliorates hypertension and increases nitric oxide metabolite excretion in angiotensin II but not N(omega)-nitro-L-arginine methyl ester hypertensive rats. Hypertension 2011;58:197-204.

15 Unemori EN, Pickford LB, Salles AL, Piercy CE, Grove BH, Erikson ME, Amento EP: Relaxin induces an extracellular matrix-degrading phenotype in human lung fibroblasts in vitro and inhibits lung fibrosis in a murine model in vivo. J Clin Invest 1996;98:2739-2745.

-16 Samuel CS, Bodaragama H, Chew JY, Widdop RE, Royce SG, Hewitson TD: Serelaxin Is a More Efficacious Antifibrotic Than Enalapril in an Experimental Model of Heart Disease. Hypertension 2014;64:315-322.

17 Bani D, Failli P, Bello MG, Thiemermann C, Bani ST, Bigazzi M, Masini E: Relaxin activates the L-argininenitric oxide pathway in vascular smooth muscle cells in culture. Hypertension 1998;31:1240-1247.

18 Jeyabalan A, Novak J, Danielson LA, Kerchner LJ, Opett SL, Conrad KP: Essential role for vascular gelatinase activity in relaxin-induced renal vasodilation, hyperfiltration, and reduced myogenic reactivity of small arteries. Circ Res 2003;93:1249-1257.

19 Dschietzig T, Brecht A, Bartsch C, Baumann G, Stangl K, Alexiou K: Relaxin improves TNF-alpha-induced endothelial dysfunction: the role of glucocorticoid receptor and phosphatidylinositol 3-kinase signalling. Cardiovasc Res 2012;95:97-107.

20 Brecht A, Bartsch C, Baumann G, Stangl K, Dschietzig T: Relaxin inhibits early steps in vascular inflammation. Regul Pept 2011;166:76-82.

21 Dschietzig T, Bartsch C, Richter C, Laule M, Baumann G, Stangl K: Relaxin, a pregnancy hormone, is a functional endothelin-1 antagonist: attenuation of endothelin-1-mediated vasoconstriction by stimulation of endothelin type-B receptor expression via ERK-1/2 and nuclear factor-kappaB. Circ Res 2003;92:32-40. 


\section{Kidney \\ Blood Pressure Research}

Dschietzig/Krause-Relle/Hennequin et al.: Relaxin and Diabetic Nephropathy

22 Collino M, Rogazzo M, Pini A, Benetti E, Rosa AC, Chiazza F, Fantozzi R, Bani D, Masini E: Acute treatment with relaxin protects the kidney against ischaemia/reperfusion injury. J Cell Mol Med 2013;17:1494-1505.

-23 Samuel CS, Hewitson TD, Zhang Y, Kelly DJ: Relaxin ameliorates fibrosis in experimental diabetic cardiomyopathy. Endocrinology 2008;149:3286-3293.

-24 Wong SE, Samuel CS, Kelly DJ, Zhang Y, Becker GJ, Hewitson TD: The anti-fibrotic hormone relaxin is not reno-protective, despite being active, in an experimental model of type 1 diabetes. Protein Pept Lett 2013;20:1029-1038.

-25 Brosius FC, III, Alpers CE, Bottinger EP, Breyer MD, Coffman TM, Gurley SB, Harris RC, Kakoki M, Kretzler M, Leiter EH, Levi M, McIndoe RA, Sharma K, Smithies O, Susztak K, Takahashi N, Takahashi T: Mouse models of diabetic nephropathy. J Am Soc Nephrol 2009;20:2503-2512.

-26 Kanetsuna Y, Takahashi K, Nagata M, Gannon MA, Breyer MD, Harris RC, Takahashi T: Deficiency of endothelial nitric-oxide synthase confers susceptibility to diabetic nephropathy in nephropathy-resistant inbred mice. Am J Pathol 2007;170:1473-1484.

27 Nakagawa T, Sato W, Glushakova O, Heinig M, Clarke T, Campbell-Thompson M, Yuzawa Y, Atkinson MA, Johnson RJ, Croker B: Diabetic endothelial nitric oxide synthase knockout mice develop advanced diabetic nephropathy. J Am Soc Nephrol 2007;18:539-550.

28 Bugger H, Abel ED: Rodent models of diabetic cardiomyopathy. Dis Model Mech 2009;2:454-466.

29 Kosugi T, Heinig M, Nakayama T, Connor T, Yuzawa Y, Li Q Hauswirth WW, Grant MB, Croker BP, CampbellThompson M, Zhang L, Atkinson MA, Segal MS, Nakagawa T: Lowering blood pressure blocks mesangiolysis and mesangial nodules, but not tubulointerstitial injury, in diabetic eNOS knockout mice. Am J Pathol 2009;174:1221-1229.

30 Takahashi T, Harris RC: Role of endothelial nitric oxide synthase in diabetic nephropathy: lessons from diabetic eNOS knockout mice. J Diabetes Res 2014;2014:590541.

-31 Danielson LA, Conrad KP: Time course and dose response of relaxin-mediated renal vasodilation, hyperfiltration, and changes in plasma osmolality in conscious rats. J Appl Physiol 2003;95:1509-1514.

-32 Samuel CS, Zhao C, Bathgate RA, Bond CP, Burton MD, Parry LJ, Summers RJ, Tang ML, Amento EP, Tregear GW: Relaxin deficiency in mice is associated with an age-related progression of pulmonary fibrosis. FASEB J 2003;17:121-123.

-33 Sharkovska Y, Kalk P, von WK, Relle K, Pfab T, Alter M, Fischer Y, Hocher B: Renoprotective effects of combined endothelin-converting enzyme/neutral endopeptidase inhibitor SLV338 in acute and chronic experimental renal damage. Clin Lab 2011;57:507-515.

34 Quaschning T, Voss F, Relle K, Kalk P, Vignon-Zellweger N, Pfab T, Bauer C, Theilig F, Bachmann S, KraemerGuth A, Wanner C, Theuring F, Galle J, Hocher B: Lack of endothelial nitric oxide synthase promotes endothelin-induced hypertension: lessons from endothelin-1 transgenic/endothelial nitric oxide synthase knockout mice. J Am Soc Nephrol 2007;18:730-740.

-35 Vignon-Zellweger N, Rahnenfuhrer J, Theuring F, Hocher B: Analysis of cardiac and renal endothelin receptors by in situ hybridization in mice. Clin Lab 2012;58:939-949.

-36 Shabanpoor F, Bathgate RA, Belgi A, Chan LJ, Nair VB, Wade JD, Hossain MA: Site-specific conjugation of a lanthanide chelator and its effects on the chemical synthesis and receptor binding affinity of human relaxin-2 hormone. Biochem Biophys Res Commun 2012;420:253-256.

-37 Yan Y, Scott DJ, Wilkinson TN, Ji J, Tregear GW, Bathgate RA: Identification of the N-linked glycosylation sites of the human relaxin receptor and effect of glycosylation on receptor function. Biochemistry 2008;47:6953-6968.

-38 Li F, Wang CH, Wang JG, Thai T, Boysen G, Xu L, Turner AL, Wolberg AS, Mackman N, Maeda N, Takahashi N: Elevated tissue factor expression contributes to exacerbated diabetic nephropathy in mice lacking eNOS fed a high fat diet. J Thromb Haemost 2010;8:2122-2132.

39 Garber SL, Mirochnik Y, Brecklin CS, Unemori EN, Singh AK, Slobodskoy L, Grove BH, Arruda JA, Dunea G: Relaxin decreases renal interstitial fibrosis and slows progression of renal disease. Kidney Int 2001;59:876-882.

40 Ikegaya N, Yoshida T, Kohsaka T, Suzuki A, Kobayashi N, Yamamoto T, Fujigaki Y, Hishida A, Kumagai H: Effects of relaxin on development of mesangial proliferative nephritis. Ann N Y Acad Sci 2009;1160:300303. 


\section{Kidney \\ Blood Pressure Research}

Kidney Blood Press Res 2015;40:77-88

DOI: 10.1159/000368484

Publisned onIIne: IVarch 05, 2015

C 2015 S. Karger AG, Basel

www.karger.com/kbr

41 Garber SL, Mirochnik Y, Brecklin C, Slobodskoy L, Arruda JA, Dunea G: Effect of relaxin in two models of renal mass reduction. Am J Nephrol 2003;23:8-12.

-42 Heeg MH, Koziolek MJ, Vasko R, Schaefer L, Sharma K, Muller GA, Strutz F: The antifibrotic effects of relaxin in human renal fibroblasts are mediated in part by inhibition of the Smad2 pathway. Kidney Int 2005;68:96-109.

-43 Mookerjee I, Hewitson TD, Halls ML, Summers RJ, Mathai ML, Bathgate RA, Tregear GW, Samuel CS: Relaxin inhibits renal myofibroblast differentiation via RXFP1, the nitric oxide pathway, and Smad2. FASEB J 2009;23:1219-1229.

-44 Chow FY, Nikolic-Paterson DJ, Atkins RC, Tesch GH: Macrophages in streptozotocin-induced diabetic nephropathy: potential role in renal fibrosis. Nephrol Dial Transplant 2004;19:2987-2996.

45 Loeffler I, Wolf G: Transforming growth factor-beta and the progression of renal disease. Nephrol Dial Transplant 2014;29:i37-i45.

46 Tirado-Rodriguez B, Ortega E, Segura-Medina P, Huerta-Yepez S: TGF- beta: an important mediator of allergic disease and a molecule with dual activity in cancer development. J Immunol Res 2014;2014:318481.

-47 Szefel J, Kruszewski WJ, Ciesielski M, Szajewski M, Kawecki K, Jankun J, Lysiak-Szydlowska W: L-carnitine and cancer cachexia. II. Effects of lipid emulsion used in total parenteral nutrition on parameters of hemostasis and inflammatory state in L-carnitine deficiency in myocytes. Oncol Rep 2012;28:324-329.

48 Kong P, Cavalera M, Frangogiannis NG: The role of thrombospondin (TSP)-1 in obesity and diabetes. Adipocyte 2014;3:81-84.

49 Sharma K: Obesity, oxidative stress, and fibrosis in chronic kidney disease. Kidney Int Suppl (2011) 2014;4:113-117.

$>50$ Forman HJ, Fukuto JM, Miller T, Zhang H, Rinna A, Levy S: The chemistry of cell signaling by reactive oxygen and nitrogen species and 4-hydroxynonenal. Arch Biochem Biophys 2008;477:183-195.

51 Tesch GH, Lim AK: Recent insights into diabetic renal injury from the db/db mouse model of type 2 diabetic nephropathy. Am J Physiol Renal Physiol 2011;300:F301-F310.

$>52$ Noiri E, Satoh H, Taguchi J, Brodsky SV, Nakao A, Ogawa Y, Nishijima S, Yokomizo T, Tokunaga K, Fujita T: Association of eNOS Glu298Asp polymorphism with end-stage renal disease. Hypertension 2002;40:535540 .

53 Prabhakar SS: Role of nitric oxide in diabetic nephropathy. Semin Nephrol 2004;24:333-344.

$>54$ Bathgate RA, Lin F, Hanson NF, Otvos L, Jr., Guidolin A, Giannakis C, Bastiras S, Layfield SL, Ferraro T, Ma S, Zhao C, Gundlach AL, Samuel CS, Tregear GW, Wade JD: Relaxin-3: improved synthesis strategy and demonstration of its high-affinity interaction with the relaxin receptor LGR7 both in vitro and in vivo. Biochemistry 2006;45:1043-1053.

$>55$ Chan LJ, Rosengren KJ, Layfield SL, Bathgate RA, Separovic F, Samuel CS, Hossain MA, Wade JD: Identification of key residues essential for the structural fold and receptor selectivity within the A-chain of human gene-2 (H2) relaxin. J Biol Chem 2012;287:41152-41164.

-56 Halls ML, Hewitson TD, Moore XL, Du XJ, Bathgate RA, Summers RJ: Relaxin activates multiple cAMP signaling pathway profiles in different target cells. Ann NY Acad Sci 2009;1160:108-111.

57 Hossain MA, Rosengren KJ, Haugaard-Jonsson LM, Zhang S, Layfield S, Ferraro T, Daly NL, Tregear GW, Wade JD, Bathgate RA: The A-chain of human relaxin family peptides has distinct roles in the binding and activation of the different relaxin family peptide receptors. J Biol Chem 2008;283:17287-17297.

-58 Hossain MA, Rosengren KJ, Samuel CS, Shabanpoor F, Chan LJ, Bathgate RA, Wade JD: The minimal active structure of human relaxin-2. J Biol Chem 2011;286:37555-37565.

59 Scott DJ, Rosengren KJ, Bathgate RA: The different ligand-binding modes of relaxin family peptide receptors RXFP1 and RXFP2. Mol Endocrinol 2012;26:1896-1906. 